\title{
Detection of early cardiac allograft vasculopathy in a high-risk transplant patient using optical coherence tomography
}

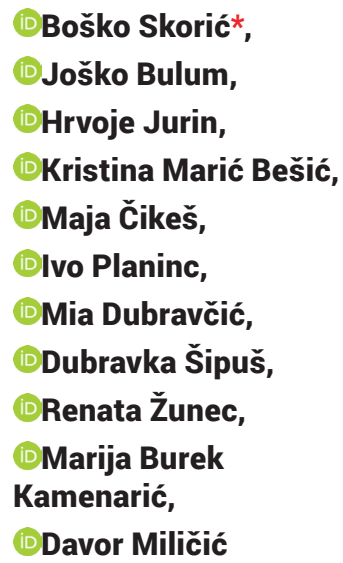

University of Zagreb School of Medicine, University Hospital Centre Zagreb, Zagreb, Croatia
KEYWORDS: optical coherence tomography, cardiac allograft vasculopathy, positive-cross match. CITATION: Cardiol Croat. 2020;15(3-4):57. | https://doi.org/10.15836/ccar2020.57

*ADDRESS FOR CORRESPONDENCE: Boško Skorić, KBC Zagreb, Kišpatićeva 12, HR-10000 Zagreb, Croatia. / Phone: +385-95-395-9910 / E-mail: bskoric3@yahoo.com

ORCID: Boško Skorić, https://orcid.org/0000-0001-5979-2346 • Joško Bulum, https://orcid.org/0000-0002-1482-6503 Hrvoje Jurin, https://orcid.org/0000-0002-2599-553X • Kristina Marić Bešić, https://orcid.org/0000-0002-4004-7271 Maja Čikeš, https://orcid.org/0000-0002-4772-5549 • Ivo Planinc, https://orcid.org/0000-0003-0561-6704 Mia Dubravčić, https://orcid.org/0000-0003-0441-4772• Dubravka Šipuš, https://orcid.org/0000-0002-5631-0353 Renata Žunec, https://orcid.org/0000-0003-2607-3059 • Marija Burek Kamenarić, https://orcid.org/0000-0003-2781-4576 Davor Miličić, https://orcid.org/0000-0001-9101-1570

|||||||||||||||||||||||||||||||||||||||||||||||||||||||||||||||||||||||||||||||||||||||||||||||||||||||||||||||||||||||||||||||||||||

Introduction: Cardiac allograft vasculopathy (CAV) is a common cause of late graft failure and mortality in heart transplant recipients. Concentric intimal proliferation that reflects immune-mediated vascular damage in the early post-transplant years is difficult to recognize by conventional coronary angiography. Optical coherence tomography (OCT) is a high-resolution intravascular imaging technique that has the potential to identify subtle early vessel wall changes and shape the therapeutic approach that may improve patients' outcomes. ${ }^{1}$

Case report: 68-year-old male patient underwent heart transplantation with positive lymphocyte crossmatch and Luminex that detected anti-HLA class I (A1, A25, B8, B57) donor-specific antibodies with MFI up to 2500. The patient was treated with steroid, antilymphocyte (rATG) induction, tacrolimus, and mycophenolate mofetil, in combination with IVIG and plasmapheresis. Graft function was preserved, biopsies showed no or mild cellular-mediated rejection (1R) with no signs of antibody-mediated rejection (AMR) with negativization of anti-A1 and -A25 antibodies. However, control biopsy after 6 months became positive for AMR. The patient was treated with steroid pulse, IVIG, plasmapheresis, and rituximab. The following biopsies were negative for AMR and the patient remained with preserved graft function. One year after transplantation we performed control coronary angiography with OCT. While coronary angiography was interpreted as normal, control OCT showed significant diffuse intimal thickening with maximal intimal thickness up to $920 \mu \mathrm{m}$ and intima/media cross-sectional media of $\geq 1$ (Figure 1). This finding prompted a change in therapy with the maximization of statin dose and introduction of everolimus in the maintenance immunosuppressive regimen.

Conclusion: This case report indicates the limitation of conventional coronary angiography in the early detection of transplant vasculopathy. OCT is able to establish the diagnosis and trigger specific therapeutic interventions like the introduction of everolimus before vascular changes become visible on conventional coronary angiography and resistant to treatment. Unfortunately, we still lack clearly defined OCT criteria for both diagnosis and treatment, but the progress in this field of transplant cardiology is promising.
RECEIVED:

February 18, 2020

ACCEPTED:

February 22, 2020

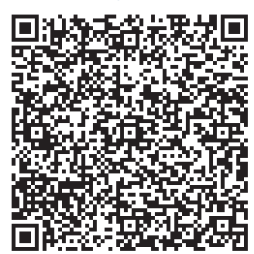

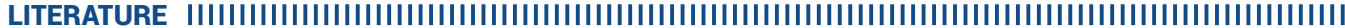

1. McGovern E, Hosking MCK, Balbacid E, Voss C, Berger F, Schubert S, et al. Optical Coherence Tomography for the Early Detection of Coronary Vascular Changes in Children and Adolescents After Cardiac Transplantation: Findings From the International Pediatric OCT Registry. JACC Cardiovasc Imaging. 2019 Dec;12(12):2492-2501. https://doi.org/10.1016/j.jcmg.2018.04.025 